\title{
The Attitudes of Nurses from an Intensive Care Unit in the Face of Errors: an Approach in Light of Bioethics ${ }^{1}$
}

\author{
Rita de Cássia Pires Coli² \\ Marcio Fabri dos Anjos $^{3}$ \\ Luciane Lucio Pereira ${ }^{4}$
}

This study analyzed the attitudes of nurses concerning the occurrence of errors in nursing procedures carried out in an Intensive Care Unit (ICU) based on the bioethics framework. This descriptive study with qualitative approach was carried out with 14 nurses from a private hospital in the city of São Paulo, Brazil. Results were analyzed according to Bardin's proposal of content analysis. The resulting themes were: acknowledging one's fallibility; acknowledging and reporting errors; hiding errors. The nurses' reports are based on considerations through the lens of bioethics: taking responsibility for an error implies acknowledging one's own vulnerabilities; acknowledging an error with responsibility implies ethical conditions in the relationships among those involved; and errors are in the context of a particular environment. This study enables re-thinking nursing practice based on bioethics, resorting to the analysis of errors focusing on the relationships between those involved.

Descriptors: Medical Errors; Bioethics; Nursing Care/Ethics; Social Responsibility; vulnerability.

\footnotetext{
${ }_{1}^{1}$ Paper extracted from Master's Thesis "O erro em procedimentos de enfermagem na unidade de terapia intensiva sob a ótica da bioética", presented to Centro Universitário São Camilo, SP, Brasil.

Centro Universitário São Camilo, SP, Brazil:

${ }^{2}$ RN, Faculty. E-mail: rita.coli@uol.com.br.

${ }^{3}$ Bioethicist, Philosopher and Theologist, Faculty. E-mail: mfabri@terra.com.br.

${ }^{4}$ RN, Ph.D. in Nursing, Faculty. E-mail luciane@saocamilo-sp.br.
}

Corresponding Author: Rita de Cassia Pires Coli Centro Universitario São Camilo Rua Raul Pompeia, 144 Vila Pompeia Cep: 05025-010 São Paulo, SP, Brasil E-mail: rita.coli@uol.com.br 


\title{
Postura dos enfermeiros de uma unidade de terapia intensiva frente ao erro: uma abordagem à luz dos referenciais bioéticos
}

O objetivo deste trabalho é analisar, a partir dos referenciais da bioética, a postura dos enfermeiros diante de ocorrência de erros em procedimentos de enfermagem na unidade de terapia intensiva (UTI). Trata-se de pesquisa descritiva, sob abordagem qualitativa, realizada com 14 enfermeiros de UTI de um hospital privado de São Paulo. A análise dos resultados foi realizada segundo a proposta de análise de conteúdo de Bardin. Os resultados evidenciados foram: reconhecendo ser falível, reconhecendo e comunicando o erro, e omitindo o erro. Os relatos dos enfermeiros formaram a base para as considerações apontadas à luz dos referenciais bioéticos: a responsabilidade diante do erro supõe o reconhecimento das próprias vulnerabilidades, assumir o erro com responsabilidade supõe condições éticas nas relações entre as pessoas envolvidas e o erro tem um ambiente. Este estudo propicia repensar a prática de enfermagem pautada na bioética, recorrendo à análise do erro focada nas relações entre os envolvidos.

Descritores: Erros Médicos; Bioética; Cuidados de Enfermagem/Ética; Responsabilidade Social; Vulnerabilidade.

\section{Postura de los enfermeros de una unidad de terapia intensiva frente al error: un abordaje utilizando referenciales bioéticos}

\begin{abstract}
El objetivo de este trabajo es analizar, a partir de referenciales de la bioética, la postura de los enfermeros delante de la ocurrencia de errores en procedimientos de enfermería, en una unidad de terapia intensiva (UTI). Se trata de investigación descriptiva, bajo abordaje cualitativo, realizado con 14 enfermeros de una UTI, en un hospital privado de Sao Paulo. El análisis de los resultados fue realizado según la propuesta de análisis de contenido de Bardin. Los resultados evidenciados fueron: reconociendo ser falible, reconociendo y comunicando el error, y omitiendo el error. Los relatos de los enfermeros formaron la base para las consideraciones apuntadas a la luz de los referenciales bioéticos; la responsabilidad delante del error supone el reconocimiento de las propias vulnerabilidades, asumir el error con responsabilidad supone condiciones éticas en las relaciones entre las personas envueltas y el error tiene un ambiente. Este estudio propicia repensar la práctica de enfermería pautada en la bioética, recurriendo al análisis del error enfocado en las relaciones entre los envueltos.
\end{abstract}

Descriptores: Errores Médicos; Bioética; Atención de Enfermería/Ética; Responsabilidad Social; Vulnerabilidad.

\section{Introduction}

Health professionals should prevent errors in their daily practice because they ought to ensure patients the right to a safe and salutary care, free of harm. However, it is acknowledged that these professionals, as any other human being, are fallible, capable of committing errors.

The book To Err is Human: Building a Safer Health System published in 2000 by the Institute of Medicine (IOM) in the USA was considered a landmark publication because it addresses the occurrence of errors and adverse events. This study was carried out in several health institutions and raised innumerable discussions about the safety of care delivered to patients ${ }^{(1)}$.

Errors can be defined as the non-intentional use of an incorrect plan to achieve an objective, or the nonsuccessful achievement of a planned action(2). Not all errors, however, end in harm. Errors that result in harm or injuries are frequently denominated 'adverse events' or harm due to interventions carried out by health 
processionals and not related to the intrinsic conditions of patients. But not all adverse events are related to errors $^{(1)}$. The terms "adverse event", "iatrogenic" and "error" are considered synonymous in this study.

Since the beginning of modern nursing, there has been a concern with errors in healthcare practice, however, bioethics has promoted changes in care standards since it is a new framework that considers human beings in their dignity and totality, including patients' safety, when they are cared for by health professionals. Bioethics emerges with the responsibility to lead health professionals to reflect about their conduct.

Questioning values, re-thinking and re-defining the praxis in professional practice in the light of bioethics, means acquiring an awareness of the fundamental purpose of nursing work, which is to care. Many of those who dedicated themselves to the study of bioethics, however, are not concerned with daily issues and few study what happens in a daily routine. Essentially, what occurs in the daily routine is the relationship between health professionals and their patients and both parts are vulnerable in this relationship ${ }^{(3)}$.

Bioethics should not be reduced to principles, though, one cannot deny that "principlism" is one of its most remarkable characteristics ${ }^{(4)}$. The principlism proposal of Beauchamp and Childress had a great impact on the development of bioethics and its success is in part due to the simplicity of its theoretical proposals and easy application to decision-making in concrete cases of biomedicine, and in part to the right choice of principles (autonomy, beneficence, non-maleficence and justice), which truly contain the cardinal points of moral life ${ }^{(4)}$.

Principlism, though necessary, has a strong deontological grounding and thus, is insufficient to allow deeper and comprehensive philosophical and ethical reflection. Gradually, in more complex bioethical situations, the theory of principles' reductionism and relative insufficiency was evidenced. Hence a proposal to replace "principles" with "references" emerged (which maintains autonomy, beneficence, non-maleficence and justice and adds others such as dignity, privacy, responsibility, prudence, and vulnerability, among others). These references are free to interact according to the demands of the analysis: rights, duties, values, feelings, and commitments, with total freedom for a pluralist, inter- and cross-disciplinary performance(5).

It is worth mentioning that bioethical references were adopted to develop this study due to its greater scope and context for bioethical discussions.
Literature addressing errors from the perspective of bioethics is incipient. Therefore, this study aimed to: analyze the attitude of nurses in the face of errors that occur in nursing procedures in an ICU in the light of bioethics.

\section{Method}

This is a descriptive study with qualitative approach. There is a concern in qualitative research with the level of reality that cannot be quantified because one works with a universe of meanings, experiences, daily life, aspirations, beliefs, values and attitudes, which correspond to a deeper scope of relationships, processes and phenomena that cannot be reduced to the operationalization of variables ${ }^{(6)}$.

The study was carried out with 14 nurses working for more than one year directly delivering care to patients in the Adult Intensive Care Unit (A-ICU) of a large private hospital in the city of São Paulo, SP, Brazil and who experienced the occurrence of errors during their practice and agreed to participate in this study. This setting was chosen because it concentrates a larger number of nursing procedures and the presence of nurses in direct care is more constant.

The participants were randomly drawn from a list of 25 nurses from the A-ICU provided by the institution. The number of interviewees was not pre-determined because the criterion of sample saturation was used(6).

Data collection was initiated after the board of the institution where the study was carried out and the Research Ethics Committee approved the project according to the requirements of Resolution CNS n. 196/96 (protocol n॰115/8).

Interviews were scheduled according to the nurses' availability and were carried out in a private place as determined by the nurses. The participants were informed of the study's objective and the participants' confidentiality was ensured. Free and informed consent forms were read, clarified and signed by the participants and the researcher.

Data were collected through a semi-structured interview that followed a script validated in a pretest. The script was composed of guiding questions that permitted the achievement of the proposed objectives:

- Have you ever, during your practice, witnessed the errors committed by the nursing staff? Describe a situation of error that caught your attention and resulted in harm to the patient;

- What do you most frequently observe when errors occur? Why?

- What would be ideal to do when errors occur? 
Answers were noted and tape-recorded. The content was transcribed verbatim with a view to keep the richness of reports for posterior analysis. Data collection took approximately 30 days (October 2008) and interviews lasted from 20 to 50 minutes.

The content analysis technique proposed by Laurence Bardin was adopted for this study. It is defined as "a set of techniques of the analysis of communications which aim to obtain, through systematic and objective procedures of description of content of messages, indicators that permeate the inference of knowledge related to the conditions of production/reception (inferred variables) of these messages"(7).

After skimming the text, data were transcribed. The following rules were considered for transcription: completeness - the reports were transcribed verbatim; no reports were omitted; representativeness - the results obtained for the sample were generalized for the whole; homogeneity - all the interviews were carried out in a similar way by the researcher, using the same script; relevance - guiding questions were validated in a pretest and met the proposed objective, and exclusivity - the reports were classified in a single category ${ }^{(7)}$.

The relevance and repetition of significant elements were considered in the construction of categories, where the same idea was contextualized through excerpts extracted from the texts. Finally, we reached the treatment of results, which corresponds to the last stage of content analysis.

\section{Results and Discussion}

The nurses' reports present their attitudes in relation to errors in nursing procedures. On the one hand, we observe they acknowledge errors; they acknowledge that, even involuntarily, one might commit an error and should communicate such an error. On the other hand, errors are ignored, they are not always communicated. Thus, the results were contextualized and analyzed as follows:

Acknowledging one's fallibility: the participants perceive themselves as people who might commit errors. They recognize that an error might occur involuntarily. The ideal is not to err; they assert that no error is intentional and, therefore, nurses stress that attention to the task should be doubled: the ideal is not to err, you know? But...it is not possible...The ideal is not to err (E1). Everybody makes mistakes, obviously! But you have to be extra careful when you're taking care of human beings. If you should have painted the wall blue but you painted it white...you go there and paint it over, but there are things that we can't turn back, you know? (E8).

Acknowledging that "all men and women are fallible and imperfect, with limitations and defects"( 8$)$ and being aware of human beings' susceptibility to err, one can say that health professionals are fallible, capable of making mistakes.

The study's participants point to the importance of acknowledging the fallible being, without forgetting the human being to whom care is being delivered. It is important to keep in mind that acknowledging an error is the basis of wisdom that enables one to deal with it. This acknowledgment is related to the professionals vulnerability, which will be somewhat mitigated, if one is aware.

Vulnerability, in its broader conception, requires the recognition that all people can be injured and demand respect. The primary contribution of nursing is then to take vulnerability as a principle of its practice and recognize professionals as human beings who are vulnerable subjects. The one who does not acknowledge vulnerability and interdependency is not capable of developing care attitudes ${ }^{(9)}$.

Recent studies indicate that it is essential to acknowledge vulnerability as a human condition and emphasize its three dimensions: the one that accrues from evolutionary constraints of our being (child, adolescent); the one that originates from the precariousness to which we are exposed to as organic and functional bodies (diseases, disorders); and that originating from relational tensions. These dimensions exemplify the meaning of vulnerability in addition to the scope of ethics in research(10).

It is necessary that managers of health institutions understand that errors occur because there are failures in the system they manage and not because their subordinates are incompetent or irresponsible. Therefore, more important than seeking for a guilty individual to punish, one should diagnose the fragility existent in the process and adopt proactive measures to prevent risks ${ }^{(11)}$.

We observe in the reports that errors are not intentional and many times the individual does not even realize s/he is making an error; it is perceived by another person: nobody intentionally makes a mistake; no mistake is intentional. Sometimes, the person is making a mistake and doesn't even realize it (E2). Thus, it wasn't something on purpose, nor intentional (E13).

It is important to reinforce the concept of slips and lapses that are implicit in unexpected actions, though there was intention to act correctly(2). 
Actions can cause adverse effects for someone without the moral subject having offended or unfairly treated the other. Thus, for moral offense to exist, harm has to be intentional or unfair. When one unfairly inflicts serious bodily injury on another or seriously harms other fundamental interests of people, then yes, harm morally prohibited by the principle of maleficence is intended ${ }^{(4)}$.

We also perceive in the subjects' reports the impossibility of always keeping attention concentrated on tasks being performed, thus intentionality directed to err, which would be highly perverse, is discarded. Attention is related to prudence and to the responsibility to care.

Prudence as a reference of bioethics, encompasses the meanings of sanity, restraint, caution, precaution, in addition to foresight, temperance, practical wisdom, reasonableness, also including experience, modesty and good sense. Prudence should also include the concepts of sophrosyne in a Socratic-platonic sense and phonesis (practical wisdom) in an Aristotelian sense ${ }^{(12)}$.

Prudence, understood as foresight and awareness, refers to the subject's attitude, to his/her personal qualities, abilities, especially to his/her facility to decide and act towards what is appropriate given the situation, in the always unique case in which a decision has to be made $^{(13)}$.

We also emphasize that the concept of responsibility is at the core of ethics. Taking responsibility is to bravely realize an imposed action and reflect upon it, taking into account the concrete situation, its uniqueness and complexity, and various ethical guiding elements according to one's specialty ${ }^{(13)}$.

Acknowledging and communicating errors: reports show the participants' personal beliefs: do not hide, rather acknowledge and communicate errors. Nurses report they communicate mistakes to the physician and supervision, whether committed by his/her team or by him/herself: and of course, you have to be aware that you cannot make mistakes every day, if it happens and you make a mistake, you have to first acknowledge it (E1). So, it is as I said: mistakes should not be hidden (E4). I've always asked the team, did you do anything wrong? Inform us, we review it, because the patient is the main one harmed (E5). I report immediately! Even if it is my mistake, you know? I go and report. Both to physicians and to supervision. So, that doesn't mean my mistakes are hidden, no, because sometimes we also end up making mistakes... (E11).

It is important to note the nurses' concern in communicating errors, because they emphasize the importance of thinking about the patient as the main one harmed and that the situation can be reversed more rapidly and major harm can be avoided if errors are communicated. This concern with reporting errors is a manifestation of the responsibility and prudence of nurses in taking an attitude in relation to the harmed patient.

Studies show that, for a problem to be solved, it needs to be first acknowledged and the next step is to make it public so methods and strategies are devised to solve it ${ }^{(14)}$.

The nurses' reports corroborate studies stressing that understanding the importance of reporting errors positively contributes to their being spontaneously acknowledged and reported(15). The perception of errors and the immediate reporting of them is essential for the implementation of interventions aimed to re-establish the conditions of patients and eliminate potential harm as fast as possible.

The individuals investigated in this study did not emphasize the participation of patients/families in issues relevant to them. Patients in these circumstances are passive and receptive to the health professionals' care. However, the nurses' concern over the importance of communicating with the family is evident in some of the reports: then, we had to report the occurrence, which is through a form we have here at the hospital for when an error occurs... he (supervisor) forwarded it to the Ethics Committee and the families were informed, everything was all right, everything was according to the legal process as it is supposed to be (E1).

Acknowledging another as a human being who might be fragile and vulnerable is essential for health professionals when caring for patients. When the relationship established between the health professional and the patient is based on respect, technique and ethics are joined and the professional is able to acknowledge his/her error in the face of patients and families ${ }^{(16)}$.

One of the main responsibilities of health professionals in the occurrence of errors is to inform the patients. The patient/family has the right to know the truth and this information is essential to maintaining their confidence in the team's work.

Although professionals acknowledge their fallibility, reporting an error is also a matter of trust and, therefore, a structured and relational environment is necessary for that to happen.

Hiding errors: nurses report that errors are not always reported. Sometimes errors are hidden, especially when they involve more than one person or teams. Nurses stress that the ideal would be to communicate errors every time they occur; however, people, including themselves, omit reporting errors when they know it 
will not have immediate repercussions for the patient. On the other hand, in case there is a doubt about the potential consequences or harm for patients, or if the error is witnessed by another, the professional reports the error: no action was taken, 'cause everything ends up hidden (E4). And sometimes, when we do something wrong, we don't report either. It stops right there, unless it is something really serious.... Otherwise you leave it behind the scenes and... I think this happens a lot (E5). I guess that, like, it's interesting: people hide a mistake when they know that it won't have immediate consequences for the patient [...] Now, if someone makes a mistake and knows nobody saw it, nobody realized it, I guess people omit reporting it (E13).

Studies indicate that only a small share of errors are reported in hospitals because these are only reported when the patient is harmed. This fact is due to the "culture of punishment" currently dominant in the health system, which often impedes a constructive and critical discussion of facts. The individual view of the error process leads to punishment and even layoffs of involved professionals. Therefore, errors are under reported, hindering the development of prevention mechanisms. Professionals in the health field are not immune to moral uncertainty, dilemmas and anguish, particularly on issues that involve human error, and they resist reporting and acknowledging an error committed during care delivery ${ }^{(17)}$.

The responsibility of professionals to communicate errors is acknowledged, however, the academic education of physicians and nurses reinforces the premise that the delivery of care should be free of errors, conveying a message that errors are unacceptable. This message leads to a simplistic understanding in which errors are seen as lack of care, attention of knowledge ${ }^{(18)}$.

This attitude is demanded both from professionals and from the patients themselves, which impedes people viewing errors in a more constructive way: mistakes are not allowed! It seems that everything has to work right. How come you can make mistakes in other professions...and in our profession you can't. A mistake can wipe out everything you've done (E13).

Studies point out that it seems that nurses have an almost exclusive concern with consequences to the patient, as if patients were the only ones suffering the consequences. Although it is unquestionable that patients are those most vulnerable, given the very condition that led to their hospitalization, consequences go far beyond the patients. They affect not only patients, but also professionals, family members, health institutions and society ${ }^{(11)}$.

\section{Final Considerations}

Based on the bioethics framework, this study analyzed the attitudes of nurses in the face of the occurrence of errors in nursing procedures in the ICU.

The reports of nurses grounded the considerations that follow in the light of the bioethical framework.

Taking responsibility for an error implies acknowledging one's own vulnerabilities - an error is the expression of one's vulnerability. Acknowledging one's own vulnerabilities is a condition of taking responsibility for an error. This study indicates the acknowledgment of human limitations, due to which nurses acknowledge themselves as fallible and, therefore, capable of making mistakes. This acknowledgment is the basis of wisdom that enables one to deal with errors. Acknowledging that errare humanum est enables professionals to perceive themselves as vulnerable when performing nursing procedures in their daily practice. On the other hand, when professionals ignore their vulnerability, their own and that of patients, they are prone to committing errors because they underestimate their chances to err and/or hinder a constructive perspective of it.

Acknowledging an error with responsibility implies ethical conditions in the relationships among the involved people - acknowledging and reporting an error shows autonomy to act in a responsible and prudent way. However, when errors do not cause harm or are not perceived by others, individuals hide them. This suggests that a punitive culture is still current. It seems fair to say that reporting an error requires that a relationship of trust be established among the professionals, patients, and institutions. Such trust does not mean collusion; on the contrary, it permits a dialog that includes the possibility of averting potential harm. It is also related to the environment in which error occurs.

Errors are in the context of a particular environment - the bioethical perception of error situates it in the context or environment where it occurs. It means not immediately reducing it to the professional who makes the mistake, but rather admitting the hypothesis that it might have social and institutional origins in addition to individual limitations. This environment is related not only to the origins of error, but also to the ways in which its occurrence is received. Awareness of such an environment seems to be essential for the whole ethical process of dealing with errors.

It is important to stress that bioethics and ethics postulate a more humanized role for health professionals because they develop the possibility of a critical and 
reflective attitude concerning the choices to be made about the practice.

In summary, this study enables re-thinking nursing practice based on bioethics, resorting to an error analysis focused also on the relationships between those involved. Keeping in mind that errors occur in a network of relationships, thus, should not be seen individually or only in technical terms, but rather in a relational way, and seek an integrated understanding of reality.

\section{References}

1. Kohn LT, Corrigan JM, Donaldson MS, editors. To err is human: building a safer health system. Committee on quality of health care in America, Institute of Medicine. Washington: National Academy Press; 2000.

2. Reason J. Human error. New York: Cambridge University Press; 1990.

3. Meira AR. Bioética e vulnerabilidade: o médico e o paciente. Rev Assoc Med Bras. 2004 jul-set; 50(1):249-50.

4. Ferrer JJ, Álvarez JC. Para fundamentar a bioética: teorias e paradigmas teóricas na bioética contemporânea. São Paulo (SP): Loyola; 2005.

5. Hossne WS. Bioética: princípios ou referenciais. Mundo Saúde 2006 out-dez; 30(4):673-6.

6. Minayo MCS, organizadora. Pesquisa social: teoria, método e criatividade. 20a ed. Petrópolis (RJ): Vozes; 2002.

7. Bardin L. Análise de conteúdo. Lisboa: Edições 70; 2004.

8. Pessini L, Barchifontaine CP. Problemas atuais de bioética. São Paulo (SP): Centro Universitário São Camilo; 2007.

9. Zoboli ELCP, Fracolli L. Bioética e ação em enfermagem em saúde coletiva. In: Barchifontaine $\mathrm{CP}$, Zoboli ELCP, organizadores. Bioética, vulnerabilidade e saúde. Aparecida (SP): Idéias e Letras; 2007. p. 139-57.

10. Anjos MF. O corpo no espelho da dignidade e da vulnerabilidade. Mundo Saúde. 2005 julho-setembro; 29(3):325-35.
11. Padilha KG. Ocorrências iatrogênicas na prática de enfermagem. In: Cassiani SHB, UETA J, organizadoras. A segurança de pacientes na utilização de medicação. São Paulo (SP): Artes Médicas; 2004. p. 111-21.

12. Hossne WS. Dos referenciais da bioética: a prudência. Bioethikos. 2008; 2(2):185-96.

13. Durand G. Introdução geral à bioética: história, conceitos e instrumentos. São Paulo (SP): Loyola; 2003.

14. Leape LL, Woods DD, Hatlie MJ, Kizer KW, Shroeder SA, Lundberg GD. Promoting patient safety by preventing medical errors. JAMA. 1998 October 28; 280(6):1444-7.

15. Carvalho VT, Cassiani SNB. Erros na medicação e conseqüências para os profissionais de enfermagem e clientes: um estudo. Rev. Latino-Am. Enfermagem. 2002 julho-agosto; 10(4):523-9.

16. Monteiro MAA, Barbosa RCM, Barroso MGT, Vieira NFC, Pinheiro AKB. Dilemas éticos vivenciados por enfermeiros apresentados em publicações de enfermagem. Rev. Latino-Am. Enfermagem 2008 novembro-dezembro; 16(6):1054-9.

17. Freitas GF, Oguisso T, Merighi MAB. Ocorrências éticas de enfermagem: cotidiano de enfermeiros gerentes e membros da comissão de ética de enfermagem. Rev. Latino-Am. Enfermagem. 2006 julho-agosot; 14(4):497-502.

18. Carvalho M, Vieira AA. Erro médico em pacientes hospitalizados. J Pediatr. 2002; 78(4):261-8. 